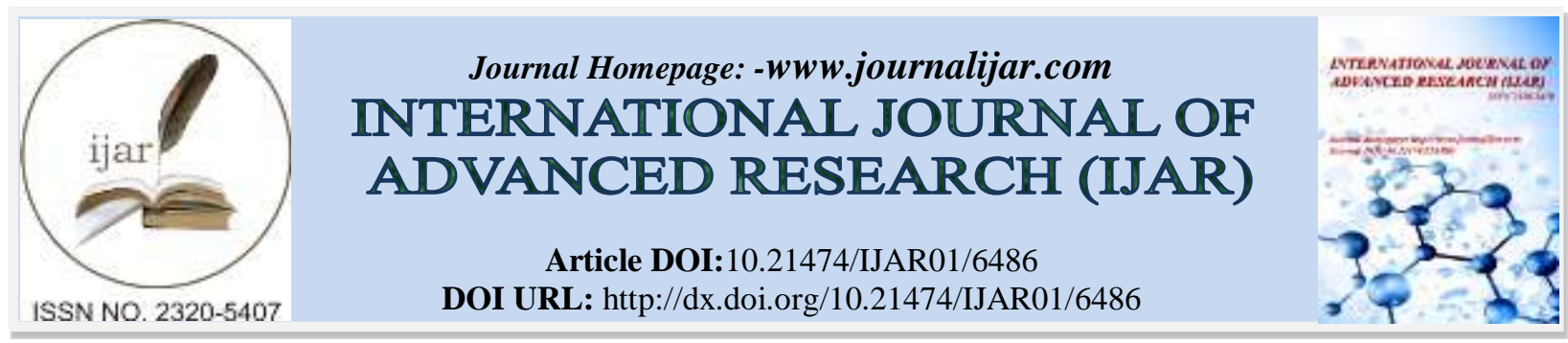

RESEARCH ARTICLE

\title{
AN ASSESSMENT OF CHALLENGES FACED BY LIVELIHOOD \& GROWTH ORIENTED ENTERPRISES IN AKSUM TOWN.
}

\section{Dr. L.V.R. Manoj Kumar ${ }^{1}$ and Mr. Beyene Gebremichael Gessesow ${ }^{2}$.}

1. Assistant professor, Accounting and Finance department Aksum University, Aksum.

2. Head of Accounting and Finance Department Aksum University, Aksum.

\section{Manuscript Info}

Manuscript History

Received: 09 December 2017

Final Accepted: 11 January 2018

Published: February 2018

Keywords:-

Livelihood, growth oriented enterprises,

Challenges, MSME's.

\begin{abstract}
Livelihood and Growth oriented enterprises are part in SMSE's. Micro, small entrepreneurs eagerly looking for new shines through these enterprises but most of the micro, small level entrepreneurs dreams are roaming in the darkness. Their desires are buried by various challenges. Some road side vendors, micro level enterprises are struggling by lack of personnel, business skills and some are continuing their enterprises with lack of capital, technology, and shortage of other resources. In this study, researcher tried to assess the challenges faced by livelihood, growth oriented enterprises in Aksum town. The study mainly focused to identify the severity of various types of challenges which are showing negative impact on enterprises. This study collected primary information through 120 respondents [60 from livelihood and 60 from growth oriented] by quota sampling technique under convenient sampling method. Secondary information gathered from Government offices in Tigray central zone, various journals and books. Data was analyzed through percentages, ranks and correlation with use of SPSS (Spatial Package for Social Sciences) 16.0. The major findings of the study indicated that the impact of challenges faced by enterprises, order of challenges priority, its severity and similarity of livelihood and growth oriented enterprises.
\end{abstract}

Copy Right, IJAR, 2018,. All rights reserved.

\section{Introduction:-}

Charles Harvie, identifies two distinct types of micro-enterprise: (1) livelihood enterprises, and (2) growth-oriented micro-enterprises ${ }^{1}$. In these enterprises, entrepreneurs are struggling with different crises which are destroying their livelihood. Entrepreneurs are entering into SMSE's with their immortal passions but finally regretting to overcome the hurdles in the high competitive world. In one side of the coin, Micro small and medium enterprises are showing radiant path to the survivalists, business entrepreneurs, small and medium investors. People those who have low skills and less capital they can easily start street business. Under growth oriented businesses, people can start opportunity enterprises named as small scale family enterprises that could be located in intermediate sector. The basic objective of these enterprises, maximize profits and accumulated wealth by taking risk. Here, basic capital, managerial skills, human resource, product specializations and technological requirements are necessary to start and continue the business ${ }^{2}$. 
Another side of the coin, livelihood enterprises are struggling with lack of commitment, accountability, transparency, job quality, personal business skills, illiteracy, innocence and high competitive environment. In case of intermediary enterprises, barricades coming through insufficient financial sources, lack of entrepreneurial capabilities, poor technical and technology support, poor productivity and less quality product, weak saving culture, miss utilization of working premises, lack of market access, lack of market information and poor managerial skills ${ }^{3}$ etc,.

Most of the studies gave priority to success stories of MSMEs but few studies have given much attention to challenges experienced by these businesses. MSMEs (SMEs) operating in Africa face many challenges that deter their growth (Nikolić, Dhamo, Schulte, Mihajlović \& Kume, 2015). The rate of business failure is alarming with only a few businesses surviving a few months to one year (Kenya National Bureau of Statistics, 2007). According to Adcorp (2014), the mortality rate of SMEs among African countries remains very high with five out of seven new businesses failing in their first year. For instance, in Uganda, one-third on new business start-ups not going beyond one year of operation while in South Africa, the failure is between $50 \%$ and $95 \%$ depending on the industry (Willemse, 2010). The major challenges facing African MSMEs are Accessing Finance, poor Electricity supply, Poor Management, high competency, Negative perception, lack of reliable information, lack of government support and lack of technology Etc ${ }^{4}$.

According to Micro and Small Enterprises (MSEs) Development Strategy of Ethiopia, the main focus of the government is creating Job opportunities through MSEs development, to reducing unemployment and alleviate poverty and enhancing MSEs to be base for industrial development in the country because Ethiopia's population is very young i.e. $45 \%$ of Ethiopians are less than 15 years old and each year an additional 1.2 million people will join the national workforce (According to the report of PHE Ethiopia Consortium).

But here in Ethiopia most of the MSMEs are family based and that are managed by women who have lower expected growth rates (Coad \& Tamvada, 2012). In a study for women owned SMEs, it is observed that Women in Ethiopia represent up to 30 percent of all SMEs owners and have a 78 percent failure rate (Bekele, \& Worku, 2008; Kipnis, 2013) ${ }^{\mathbf{5}}$. Another biggest problem is getting credit from authorised sector. As per 'Doing Business Report $2015^{\prime}$ published by the World Bank Group, Ethiopia is ranked $165^{\text {th }}$ out of 189 in getting credit. Past experience shows that, while many MSE start-ups may survive, many others fail in a few years leaving only a small percentage to grow into medium and large enterprises. For example, if there are half a million MSEs(500,000), and 99\% are not able to develop into medium or large enterprises or fail completely, this still means that $1 \%$ - or 5,000 - become medium sized enterprises, and eventually may become large scale businesses (Ministry of Urban Development and Housing-Ethopia). A National survey conducted by Central Statistics Agency (CSA) in 2007 indicates that more than 1.3 million people in the country are engaged in MSEs sector. But a large number of MSEs are unable to grow (expand in terms of employment) and remain to be survival (non-growing) type which cannot provide employment ${ }^{6}$. Under Ministry of urban development and Housing, Ethiopia Micro and small enterprises development and strategies report says that, SMSEs are facing not only financial problems other than this production, marketing, industry extension services, technology and human resource problems.

In Tigray region, there were around 114,258 MSMEs are engaged in different sectors,(Tigray Regional State agency micro and small enterprise,2016), According to MSEs Aksum town office (2016) there were 4100, micro, small and enterprise engaged in the developmental oriented sectors in Aksum town. From those 4100 MSMEs operators in construction 600, manufacturing 850, service700, urban agriculture 750 and trade are 1200. This town is also not exceptional than other places in Ethiopia. Here also MSMEs are struggling with various problems. Most of the entrepreneurs are running livelihood and growth oriented businesses which capital is less than 50,000 birr in service and 100,000 birr in Industrial sector. Few are running small and medium size enterprises by investing millions of amount. Majority of the entrepreneurs are surviving with Cafeteria and restaurant, beauty salons, internet café, garage and assembly work, fruit and vegetable production and selling, food processing and Beverages, Metal works, wood work including furniture, traditional handicrafts and jewellery, whole sale and retail trade etc,.

\section{Statement of Problem:-}

Most of the studies discussed about challenges of MSMEs and plenty of causes found by the various studies but everywhere the common question is arising, Why MSMEs are not surviving properly? What kind of challenges commonly troubling them? Finding the acuity of challenges and assessing the impact of challenges very important. 
Without knowing the severity of problem identifying solutions are difficult to small investors, entrepreneurs as well as government.

In this study, researcher studied and tried to assess the survival problems in MSMEs by the classification of two parts. One is livelihood enterprises and second is growth oriented enterprises. Before this, various researchers defined MSME based on labour and capital. In that, again they divided service and industrial sector.

Researcher observed in the Aksum town, several entrepreneurs are coming and very short period closing their businesses. Not only in micro level or street side enterprises, some of middle level enterprises are also same and most of the enterprises are not upgrading to next level. Lack of capital, lack of skill, lack of business communication, lack of administration skills etc., are showing causes by entrepreneurs but no one is expressing the common challenges and severity of challenge to wind up the business. Finally the researcher recognized that the importance to assess the severity of challenges in MSME's in the Aksum town.

\section{Objectives of the study:-}

The study has both general and specific objectives,

General Objective: assess the challenges faced by lively hood \& growth oriented enterprises in Aksum town.

Specific Objectives:

1. Assess the challenges faced by lively hood Enterprises.

2. Assess the challenges faced by Growth oriented Enterprises.

3. Identify the severity of challenges.

4. Identify the similarities of challenges in both Enterprises.

\section{Limitations of the Study:-}

Researcher did not consider all type of MSMEs in service and manufacturing sector. This study concentrated Micro, small level of enterprises. Medium level enterprises which capital is more than 1.5 million in manufacturing and 500,000 in service sector not considered. Particularly this study collected information from which enterprises are available in the Aksum town. Respondent's age also permitted between 20 to 60 years.

\section{Literature Review:- \\ Definition of MSME's:-}

Analysis of different SMEs definitions worldwide reveal that it is very difficult to arrive at a common definition. In fact one study by Auciello (1975) in 75 countries found more than 75 definitions was used in the target countries. This demonstrates very well that there is no common accepted definition of SMEs. Depending on the country and industry, business size, assets and products, the definitions will continue to vary. Even though there is no common acceptance, some definitions about MSMEs mentioned below.. (NCR, South Africa)

\section{Survivalist enterprise:-}

The income generated is less than the minimum income standard or the poverty line. This category is considered pre-entrepreneurial, and includes hawkers, vendors and subsistence farmers. In practice, survivalist enterprises are often categorised as part of the micro-enterprise sector.

\section{Micro-enterprise:-}

The turnover is less than the value added tax (VAT) registration limit. These enterprises usually lack formality in terms of registration. They include, for example, spaza shops, minibus taxis and household industries. They employ no more than 5 people.

\section{Very small enterprise:-}

These are enterprises employing fewer than 10 paid employees, except for the mining, electricity, manufacturing and construction sectors, in which the figure is 20 employees. These enterprises operate in the formal market and have access to technology.

\section{Small enterprise:-}

The upper limit is 50 employees. Small enterprises are generally more Established than very small enterprises and exhibit more complex business practices. 


\section{Medium enterprise:-}

The maximum number of employees is 100 or 200 for the mining, electricity, manufacturing and construction sectors. These enterprises are often characterised by the decentralisation of power to an additional management layer ${ }^{7}$.

The new micro and small enterprises development strategy of Ethiopia (published 2011), enterprises are classified based on size of capital and labour as follow:

\begin{tabular}{|l|l|l|l|}
\hline Level of the enterprise & Sector & $\begin{array}{l}\text { Human } \\
\text { power }\end{array}$ & Total asset/capital \\
\hline \multirow{2}{*}{ Micro enterprise } & Service & $\leq 5$ & $\leq 50,000$ \\
\cline { 2 - 4 } & Industry & $\leq 5$ & $\leq 100,000$ \\
\hline \multirow{2}{*}{ Small enterprise } & Service & $6-30$ & 50,001 to 500,000 birr \\
\cline { 2 - 4 } & Industry & $6-30$ & 100,001 to 1.5 million birr \\
\hline \multirow{2}{*}{ Medium enterprise } & Service & $30-100$ & 500,001 to 20 million birr \\
\cline { 2 - 4 } & Industry & $30-100$ & $>1.5$ million to 20 million birr \\
\hline
\end{tabular}

Based on the above definition, they classified three segments like Micro, Small \& medium size enterprises. Every segment subdivided by service and industry enterprises. Service sector representing 25 enterprises like.. Rural and small scale transport services, Cafeteria and restaurant, Warehousing services, Tourist services, beauty salons, internet café, garage and assembly work, poultry, animal feed processing and fruit and vegetable production and selling etc., manufacturing sector contains four branches viz., Manufacturing, construction, trading, mining and quarrying sector. Here most of the entrepreneurs are surviving with their monthly or day by day incomes named as livelihood or street vendors.

Livelihood enterprises, which do not generate much employment and are unlikely to grow, but whose development and growth as a whole can generate more employment as well as alleviate poverty. These can start with micro level capital and more comfortable to road side businesses named street Vendors. (Charles harvie,2004)Street vendors are businesses made up of a single person or a household based with family members helping to sell the products (Butale, 2001; Harvie, 2003, Ohiokpahei, 2003) ${ }^{8}$,. In addition, (Bharan, 2004) ${ }^{9}$ states that a street vendor is a person who offers goods and services for sale to the public without having a permanent built up structure but with temporary static structure or mobile stall.

\section{Challenges \& failures of MSMEs:-}

According to the 2007 Informal Sector Survey (2009), many street vendors enterprises in Botswana are faced with the following challenges; non-payment of goods and services supplied on credit to their customers; high competition, lack of managerial skills which were the most constraints among operators, lack of space for business operations and lack of credit facilities ${ }^{\mathbf{1 0}}$.

In the United States, over 50\% of small businesses fail in the first five years. Globally, the top ten causes of failure in small businesses are: lack of skills and experience in operating businesses, insufficient capital, poor physical location, poor inventory management, over-investment in fixed assets, poor credit arrangements, personal use of business funds, unexpected growth, still competition, and low sales (Asiedu,Freeman and Nti-Addae, 2012) ${ }^{\mathbf{1 1}}$.

According to the enterprise survey conducted by the World Bank in 2007 (Yang, 2011 as state Hyder and Lussier, 2016) ${ }^{12}$, the top barriers that business firms in Pakistan consider as obstacles to business performance are the lack of consistent electricity and political instability ${ }^{13}$.

According to Cant (2012), 40\% of new business ventures in South Africa fail in their first year, 60\% in their second year, and $90 \%$ in their first 10 years of existence ${ }^{14}$. Small and medium-sized enterprises in Ethiopia suffer from poor infrastructural development, lack of foreign direct investment, shortage of foreign currency, and over-regulation ${ }^{15}$ During 2014, in the Republic of Srpska 3,242 new individual entrepreneurs were registered, while 4,965 were shut down. In addition, 839 new SMEs were registered, while 569 SMEs were shut down (Agency for development of small and medium-sized enterprises of the Republic of Srpska, 2015, p. 5) ${ }^{\mathbf{1 6}}$. 
SMEs businesses range from very small micro-firms run by one or two persons and very slow growth or no growth to fast growing medium businesses earning millions of dollars and majority employing as many as 250 employees (Fjose et al., 2010) ${ }^{\mathbf{1 7}}$.

Ericson and Pakes predicted that small firms die more often than their large counterparts in the same industry ${ }^{\mathbf{1 8}}$. About $80 \%$ of Small and medium enterprises are stifled because of poor financing and other associated problems ${ }^{19}$ Banks may avoid providing financing to certain types of SMCFs, in particular, start ups and very young firms that typically lack sufficient collateral, or firms whose activities offer the possibilities of high returns but at a substantial risk of loss. These include policies regulations, inadequate financial infrastructure, firm regulations, trade regulations, tax regulations, changing government policies, tax rates, corruption, labour regulations, cost of capital, and keen competition for limited opportunities (Uriyo 2004) ${ }^{\mathbf{2 0}}$.

Most of the studies mentioned challenges and failures of MSMEs but these all identified failure reasons without categorization of MSMEs. Based on MSMEs definition, there are minimum 3 categories like micro, small and medium size enterprises. If we observe clearly, micro level indicates very small business size like street vendors, small enterprises are representing half of micro level remaining half to the growth level like general stores, welding shops etc, and finally medium level represents wholesale, manufacturing sectors etc., these level of enterprises capital, manpower, technology are different compare with remaining enterprises. Solving for these variances, the study particularly classified the enterprises in to two categories viz., Livelihood and growth oriented enterprises which are invested less than 50,000 birr for livelihood and more than 50,000 birr for growth oriented.

\section{Methodology:-}

Area of the study:-

Axum is situated in central administrative zone of Tigray. Geographically Axum is located west of Adwa, East of WukroMaray, North of EdagaSelus and south of Roma at $1041 \mathrm{Km}$ distance from Addis Ababa. According to Central Statistical Agency of Ethiopia (CSA), as of July 2012 (est.) the town of Axum's population was 56,576. The census indicated that 30,293 of the population were females and 26,283 were males. According to Axum city administration office of plan and finance development plan process (2010) In the Axum town, 2181 households were doing various types of businesses like restaurants, bars, merchants, grocery and art gallery etc. almost 4282 Households were doing non business activities like government, non government employees, farmers, priests and daily workers etc. According to MSEs Aksum town office (2016) there were 4100, micro, small and enterprise engaged in the developmental oriented sectors in Aksum town.

\section{Data Collection Methods:-}

Researcher collected information through primary and secondary data. Primary data refers to the information obtained firsthand by the researcher on the variables of interest for the specific purpose of the research. Here, researcher used questionnaire with formal, informal questions and by the support of language translator, conducted field trips for collecting the information from individual Entrepreneurs and enterprise managers those who running livelihood and growth oriented businesses.

\section{Target Population:-}

The population of this study was covered Livelihood and growth oriented enterprises in the Aksum town. These are subparts of SMSEs. Purposively researcher separated enterprises by two categories viz., which are less than 50,000 birr and greater than 50,000 birr. In this study, Researcher collected information from livelihood enterprises those capital less than 50,000 birr like Cafeteria, small restaurant, beauty salons, internet café, vegetable, fruit sellers and small general stores etc. and also considered growth oriented enterprises those capita is more than 50,000 birr as well as representing to the manufacturing sector like Metal works, wood work including furniture, jewellery, whole sale and retail trade, restaurants etc.

\section{Sampling size and technique:-}

Researcher for his convenient purpose randomly conducted 150 interviews with Individual owners, managers or partners of enterprises. 12 different natures of enterprises he opted based on availability. Systematically, 10 to 12 questionnaires distributed to every nature of business. Out of 150 completed questionnaires, only 142 were accepted because some of the entrepreneurs not responded well. In these 142 questionnaires, 82 respondents belong to livelihood, remaining 60 from growth oriented. Then researcher selected the quota sampling technique for similar 
comparison of the information. Finally 60 from livelihood and 60 from growth oriented accepted. Remaining 22 questionnaires in livelihood, removed 1 from every 4 questionnaires the rest of 2 questionnaires removed without any sampling technique.

\section{Data Analysis techniques:-}

This study used the descriptive design with descriptive techniques. The researcher arranged questionnaire by 3 parts viz., demographic, livelihood and growth oriented enterprises. Here, demographic questions are common for all respondents remaining questions separated based on capital size. The survey comprised questionnaire with mostly closed questions. The respondents answers were collected through questionnaire by the survey instrument using a 5Likert scale where $5=$ was strongly Agree, $3=$ Neutral and $1=$ strongly disagree. Open ended questions were used at the end of the closed ended questions to get additional information not captured in the closed ended questions. To assess the challenges, researchers used percentages, Ranks, arguments and opinions were computed. For simplicity, percentages of corresponding responses for each variable were discussed. Responses of respondents were electronically coded and saved for analysis using Statistical Package for Social Sciences (SPSS) 16.

\section{Findings And Discussion:-}

The researcher collected demographic information from the respondents in the Aksum town. The response rate was 94.667\% through 142 questionnaires. Out of these, he was considered for the analysis 120 questionnaires it was $80 \%$ in the overall distribution. For this research, $56.67 \%$ men and $43.33 \%$ women respondents were participated. From that, $50 \%$ belongs to Livelihood enterprises remaining from growth oriented. Under growth oriented enterprises, men participation is more than the women it is almost 38\% [26.67+11.67] out of 56.67\%, moreover men only handling the enterprises in all aspects. These are organizing restaurants, timber \& woodworks, metal works and other productive oriented enterprises. Women entrepreneur participation is low out of 60 owners only $14[11.67 \%=$ $(8.33+3.33)]$ responded as owners. In these also, only 4 respondents are working as managers. Lack of managerial skills, poor financial backgrounds, market awareness and public interactions are basic causes for their inactive participation.

Table 1:- Demographic Profile

\begin{tabular}{|l|l|l|l|l|l|}
\hline \multirow{2}{*}{ Gender } & Livelihood & Growth oriented & Total \\
\cline { 2 - 5 } & Owner & $\begin{array}{l}\text { Manager/Co- } \\
\text { partner }\end{array}$ & Owner & $\begin{array}{l}\text { Manager/ Co- } \\
\text { partner }\end{array}$ & \\
\hline Men & $18[15 \%]$ & $4[3.33 \%]$ & $32[26.67 \%]$ & $14[11.67 \%]$ & $68[56.67 \%]$ \\
\hline Women & $36[30 \%]$ & $2[1.67 \%]$ & $10[8.33 \%]$ & $4[3.33 \%]$ & $52[43.33 \%]$ \\
\hline Total & $54[45 \%]$ & $6[5 \%]$ & $42[35 \%]$ & $18[15 \%]$ & $120[100 \%]$ \\
\hline & \multicolumn{2}{|c|}{$50 \%$} & \multicolumn{2}{|c|}{$50 \%$} & \\
\hline
\end{tabular}

Source: Primary Data

In the livelihood enterprises, respondents provided quite opposite information compare with growth oriented enterprises. Here, $31.67 \%$ [30\%+1.67\%] out $43.33 \%$ women respondents were depended on livelihood enterprises. These are surviving by small general \& fancy stores, groceries, house utensils, fruits \& vegetable shops and cafeterias etc., they do not know any special skill, business knowledge and financial support. Every day they are fighting for bread and butter. Most of the women taking care their children by their little earnings. The remaining $18.33 \%$ of men running barbershops, mobile services, electricity, shoe and meat selling shops etc.

Table 2:- Demographic profile (Education and marital status)

\begin{tabular}{|c|c|c|c|c|c|}
\hline \multirow[t]{2}{*}{ Education } & \multicolumn{2}{|c|}{ Livelihood } & \multicolumn{2}{|c|}{ Growth oriented } & \multirow[t]{2}{*}{ Total } \\
\hline & Men & Women & Men & women & \\
\hline Uneducated & $5[4.17]$ & $12[10]$ & $5[4.17]$ & $2[1.67]$ & $24[20 \%]$ \\
\hline 1 to $5^{\text {th }}$ standard & $8[6.67]$ & $13[10.83]$ & $5[4.17]$ & $2[1.67]$ & $28[23.33 \%]$ \\
\hline $6^{\text {th }}$ to $12^{\text {th }}$ & $7[5.83]$ & $8[6.67]$ & $21[17.5]$ & $4[3.33]$ & $40[33.33 \%]$ \\
\hline Graduation & $2[1.67]$ & $4[3.33]$ & $13[10.83]$ & $6[5.00]$ & $25[20.83 \%]$ \\
\hline Masters and above & - & $1[33.33]$ & $2[66.66]$ & - & $3[2.5 \%]$ \\
\hline Total & $22[18.33]$ & $38[31.67]$ & $46[38.33]$ & $14[11.67]$ & $120[100 \%]$ \\
\hline \multicolumn{6}{|l|}{ Marital Status } \\
\hline Marital status & \multicolumn{2}{|c|}{ Livelihood } & \multicolumn{2}{|c|}{ Growth oriented } & Total \\
\hline
\end{tabular}




\begin{tabular}{|l|l|l|l|l|l|}
\hline & \multicolumn{1}{|c|}{ Men } & \multicolumn{1}{c|}{ Women } & \multicolumn{1}{c|}{ Men } & \multicolumn{1}{c|}{ women } & \\
\hline Unmarried & $11[9.17]$ & $9[7.5]$ & $8[6.67]$ & $4[3.33]$ & $32[26.67 \%]$ \\
\hline Married & $9[7.5]$ & $21[17.50]$ & $33[27.50]$ & $8[6.67]$ & $71[59.17 \%]$ \\
\hline Divorced & $2[1.67]$ & $8[6.67]$ & $5[4.17]$ & $2[1.67]$ & $17[14.17 \%]$ \\
\hline Total & $22[18.33]$ & $38[31.67]$ & $46[38.43]$ & $14[11.67]$ & $120[100 \%]$ \\
\hline
\end{tabular}

Source: Primary Data

In this study their education qualification also helpful to assess the current situation of enterprises. Here, out of 120 respondents $20 \%$ are uneducated in that, lively hood enterprises $14.17 \%$ [4.17+10]. Almost 25[12+13] women out of 120 studied below $5^{\text {th }}$ standard, these percentage was indicated 20.83. Lack of educational awareness, lack of free education facilities, family burdens, less financial support etc., are main causes to them and most of women migrated from near villages because of unhealthy agricultural environment. $33.33 \%$ respondents studied between $6^{\text {th }}$ to $12^{\text {th }}$ grades. In these, 25 respondents only in growth oriented enterprises. These percentages are indicating those who have money, and staying in Aksum town they gave priority to education and utilized local educational institution services. Graduation and above courses also most of the respondents completed from growth oriented sector only.

Surprisingly, both type of enterprises marital status comparatively similar. Almost $40 \%$ of entrepreneurs were unmarried and divorced. In case of livelihood, unmarried \% is high. Respondents were expressed their poor financial condition is main cause. Most of the divorced respondents were not taken diverse legally but together not living with their personal disparities. One thing should be appreciate to the respondents those who married, because maximum married respondents are working and co-operating each other to develop their financial and wealth conditions.

Table 3 is disclosing what kind of business activities are doing by livelihood and growth oriented enterprises. Because, capital, human resource, infrastructure and technical support etc., are essential to run any type of enterprise. With the help of table 3, researcher tried to provide clarity of business selection by the livelihood \& growth oriented enterprises.

Table 3:- An Assessment of enterprises participation in various businesses

\begin{tabular}{|c|c|c|c|c|c|}
\hline \multirow[t]{2}{*}{ Sl.No } & \multirow{2}{*}{ Enterprise Name } & \multicolumn{2}{|c|}{ Livelihood } & \multicolumn{2}{|c|}{ Growth Oriented } \\
\hline & & Sample & C.\% & Sample & C.\% \\
\hline 1 & Fruits, juice and Vegetable sellers & $9(15 \%)$ & 15 & $1(1.67 \%)$ & 1.67 \\
\hline 2 & $\begin{array}{l}\text { Bakery, small cafeteria, milk products, bread, } \\
\text { inzeera, makers and sellers }\end{array}$ & $8(13.33)$ & 28.33 & $2(3.33)$ & 5 \\
\hline 3 & $\begin{array}{lllll}\begin{array}{l}\text { Electronics, mobile } \\
\text { developers }\end{array} & \text { Services } & \text { and } & \text { software } \\
\end{array}$ & $8(13.33)$ & 41.67 & $2(3.33)$ & 8.33 \\
\hline 4 & Beauty salons and Barber shops & $7(11.67)$ & 53.33 & $3(5)$ & 13.33 \\
\hline 5 & General stores and Drug stores, hole sellers & $6(10)$ & 63.33 & $4(6.67)$ & 20 \\
\hline 6 & Hotels \& Restaurants & $3(5)$ & 68.33 & $7(11.67)$ & 31.67 \\
\hline 7 & Metal work, Welding and Engineers & $4(6.67)$ & 75 & $6(10)$ & 41.67 \\
\hline 8 & Wood cutters and furniture makers & $2(3.33)$ & 78.33 & $8(13.33)$ & 55 \\
\hline 9 & Traditional hand crafts and jewelleries & $3(5)$ & 83.33 & $7(11.67)$ & 66.67 \\
\hline 10 & Motor vehicle spares and Garage works & $4(6.67)$ & 90 & $6(10)$ & 76.67 \\
\hline 11 & Construction Material Products \& sellers & $2(3.33)$ & 93.33 & $8(13.33)$ & 90 \\
\hline 12 & Readymade garments & $4(6.67)$ & 100 & $6(10)$ & 100 \\
\hline \multicolumn{2}{|r|}{ 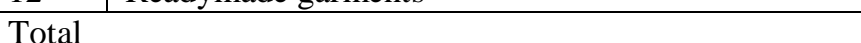 } & 60100 & 100 & 60 & 100 \\
\hline
\end{tabular}

Source: Primary data $\quad$ (C\% means Cumulative \%)

In the above table, $63.33 \%$ businesses are running only by livelihood enterprises. These all are running very small businesses and their capital less than 10,000 ETB in that, some of doing their sales on footpath without any permanent roof. These people started business with below 5,000ETB. Here most of the entrepreneurs are individuals they don't have any human support. The remaining 35.67\%[100\%-63.33] invested amount between 20,000 to 50,000 ETB and maintaining 2 or 3 workers. Those who have little bit financial source, human support, managerial skills etc., are not selecting 1 to 5 types of businesses. They mentioned, these are less profit and social dereorganisation. Even though some of entrepreneurs are running these type businesses with more profits under growth oriented enterprises like "Kudda Juice point". 
Serial No. 6 to 12, $80 \%$ businesses [ 1 to 5 only 20\%] are running by growth oriented here livelihood proportion very less. These enterprises requires more than 50,000ETB. Some of invested more than 1 million also. Their human power and other resources are also very high compare with lively hood. Here, male participation is more. Restaurants, furniture sellers, and construction materials proportion is more almost $50 \%$ of enterprises doing transactions by by these only. Under livelihood enterprises also running these businesses but with less capital and lack of human resource they are not showing any impact on market.

Table 4:- An assessment of challenges in livelihood enterprises

\begin{tabular}{|c|c|c|c|c|c|c|}
\hline & Challenges faced by enterprises & $\begin{array}{l}\text { Strongly } \\
\text { Disagree }\end{array}$ & Disagree & Neutral & Agree & $\begin{array}{l}\text { Strongly } \\
\text { agree }\end{array}$ \\
\hline i. & $\begin{array}{l}\text { Lack of education, business and } \\
\text { entrepreneur skills }\end{array}$ & $\begin{array}{c}2 \\
(3.33)\end{array}$ & $\begin{array}{c}5 \\
(8.33)\end{array}$ & $\begin{array}{c}9 \\
(15)\end{array}$ & $\begin{array}{c}24 \\
(40)\end{array}$ & $\begin{array}{c}20 \\
(33.33)\end{array}$ \\
\hline ii. & $\begin{array}{l}\text { Lack of family support \& human } \\
\text { resource }\end{array}$ & - & $\begin{array}{c}2 \\
(3.33)\end{array}$ & $\begin{array}{c}13 \\
(21.66)\end{array}$ & $\begin{array}{c}29 \\
(48.33)\end{array}$ & $\begin{array}{c}16 \\
(26.67)\end{array}$ \\
\hline iii. & $\begin{array}{l}\text { Lack of Capital and Financial sources } \\
\text { and no saving culture. }\end{array}$ & - & - & $\begin{array}{c}8 \\
(13.33)\end{array}$ & $\begin{array}{c}22 \\
(36.67)\end{array}$ & $\begin{array}{c}30 \\
(50)\end{array}$ \\
\hline iv. & $\begin{array}{l}\text { Poor technical and technology } \\
\text { support (including power facility) }\end{array}$ & $\begin{array}{c}12 \\
(20)\end{array}$ & $\begin{array}{c}17 \\
(28.33)\end{array}$ & $\begin{array}{c}15 \\
(25)\end{array}$ & $\begin{array}{c}12 \\
(20)\end{array}$ & $\begin{array}{c}4 \\
(6.67)\end{array}$ \\
\hline v. & $\begin{array}{l}\text { Poor productivity and less quality } \\
\text { product }\end{array}$ & $\begin{array}{c}4 \\
(6.67)\end{array}$ & $\begin{array}{c}16 \\
(26.67)\end{array}$ & $\begin{array}{c}12 \\
(20)\end{array}$ & $\begin{array}{c}20 \\
(33.33)\end{array}$ & $\begin{array}{c}8 \\
(13.33)\end{array}$ \\
\hline vi. & Lack of market information \& access & $\begin{array}{c}10 \\
(16.67)\end{array}$ & $\begin{array}{c}17 \\
(28.33)\end{array}$ & $\begin{array}{c}5 \\
(8.33)\end{array}$ & $\begin{array}{c}16 \\
(26.67)\end{array}$ & $\begin{array}{c}12 \\
(20)\end{array}$ \\
\hline vii. & $\begin{array}{l}\text { Lack of transportation and timely } \\
\text { import or export of goods }\end{array}$ & $\begin{array}{c}14 \\
(23.33)\end{array}$ & $\begin{array}{c}22 \\
(36.67)\end{array}$ & $\begin{array}{c}6 \\
(10)\end{array}$ & $\begin{array}{c}13 \\
(21.67)\end{array}$ & $\begin{array}{c}5 \\
(8.33)\end{array}$ \\
\hline viii. & $\begin{array}{l}\text { Wrong place of business or Miss } \\
\text { usage of work premises }\end{array}$ & $\begin{array}{c}6 \\
(10)\end{array}$ & $\begin{array}{c}16 \\
(26.67)\end{array}$ & $\begin{array}{c}4 \\
(6.67)\end{array}$ & $\begin{array}{c}24 \\
(40)\end{array}$ & $\begin{array}{c}10 \\
(16.67)\end{array}$ \\
\hline ix. & Highly competitive environment & - & $\begin{array}{c}4 \\
(6.67)\end{array}$ & $\begin{array}{c}12 \\
(20)\end{array}$ & $\begin{array}{c}32 \\
(53.33)\end{array}$ & $\begin{array}{c}12 \\
(20)\end{array}$ \\
\hline X. & Government and tax regulations & $\begin{array}{c}28 \\
(46.67)\end{array}$ & $\begin{array}{c}16 \\
(26.67)\end{array}$ & $\begin{array}{c}6 \\
(10)\end{array}$ & $\begin{array}{c}6 \\
(10)\end{array}$ & $\begin{array}{c}4 \\
(6.67)\end{array}$ \\
\hline
\end{tabular}

Table 4 is disclosing 10 different types of challenges which are facing by Livelihood enterprises. Respondents responded clearly based on every challenge. Researcher also arranged all challenges in proper sequence. Primarily, first 5 challenges representing their internal conditions remaining are belongs to external environment.

73.33\% [40+33.33] respondents agreed that, lack of education, lack of business skill are major challenge to livelihood enterprises. Only $11 \%$ respondents are disagreed because these enterprises are secondary source to them, their family people are doing other works and they also studied above $10^{\text {th }}$ grade. As per their opinion, by the education, business skills will not increase, these skills will come from the circumstances or from their ancestors but most of the livelihood entrepreneurs are doing businesses without any family support and struggling for day today surviving.

75\%[48.33+26.67] respondents agreed that lack of family support is major challenge because most of these enterprises running by ladies only. Those who took diverse, who neglected by man support, who doesn't know any other work, who are not physically strong, orphans are attracting to these type of businesses. When coming to the lack of financial support, more than $86 \%[36.67+50]$ agreed that lack of financial support is one of the biggest hurdle to start and continue the enterprise. In that, $50 \%$ respondents strongly agreed, more over no one opposed. So, it is a clear indication that all livelihood entrepreneurs are struggling for financial sources. No financial institute is supporting them because they do not have any collateral assets for mortgage and no one ready to give guarantee behalf of them. Some micro-financial institutions are providing services but some of street vendors they don't have permanent house address also. These entrepreneurs are taking hand loans for short term with high interest rates almost $12 \%$ to $20 \%$. Finally, they are failing to re-pay the loan and losing their small business shelter also.

While coming to the iv, $\mathrm{v}$ challenges most of the enterprises are not using any high technical equipment and not participating in the productive activities. Because of that, almost 50\% respondents disagreed that the challenge of 
poor technology. Some of restaurants, bread makers, juice maker's are maintaining good quality but those who are depending on entry pro trade, fancy and clothe sellers etc., are agreed that good quality raw material is not available in the whole sale market because of that our production also quoting less standards.

Lack of market information and lack of transportation are not that much related to livelihoodd enterprises because, they are purchasing huge quantity of items as well as not involving in to exports. These enterprises are concentrating only in local market with local facilities. Weekly or monthly once these are going near towns individually and purchasing small quantity of items. In the above table, respondents also similarly expressed their opinion some of agreed and some of disagreed. Another challenge is Correct location of the enterprises here also respondents gave mixed result 56\% are agreed and above agreed remaining expressed disagree and neutral opinions because, these entrepreneurs sales almost constant and they can start their business any residential area or in the main market location based on demand of product. Because of that they did not particular about exact location.

Another major challenge of livelihood enterprises is competition. $73.33 \%$ respondents were selected agreed and strongly agreed option and no one strongly disagreed. Here customers are limited and their requirements also in the particular frame no one purchase more items and also less proportion of new customers. These enterprises size is small but more people those who are in middle class and below middle class are involving in the same type of businesses. Example, Bus station area in Aksum, more than 20 general stores are available because, these are became common to all. Any special qualification and skill no need more over minimum income generating purpose these are comfortable. Finally last challenge but not least is that government involvement in livelihood enterprises. $72.33 \%$ respondents were under disagreed and strongly disagreed options. Because, government charging very small registration fee from them and no other conditions are implementing. Few of these are not taking any permission from the government and doing their business transactions.

Table 5:- An assessment of challenges in growth oriented enterprises

\begin{tabular}{|c|c|c|c|c|c|c|}
\hline SI.No & Challenges faced by enterprises & $\begin{array}{l}\text { Strongly } \\
\text { Disagree }\end{array}$ & Disagree & Neutral & Agree & $\begin{array}{l}\text { Strongly } \\
\text { agree }\end{array}$ \\
\hline i. & $\begin{array}{l}\text { Lack of education, business and } \\
\text { entrepreneur skills }\end{array}$ & - & $\begin{array}{c}17 \\
(28.33)\end{array}$ & $\begin{array}{c}21 \\
(35)\end{array}$ & $\begin{array}{c}16 \\
(26.67)\end{array}$ & $\begin{array}{c}6 \\
(10)\end{array}$ \\
\hline ii. & $\begin{array}{l}\text { Lack of family support \& human } \\
\text { resource }\end{array}$ & - & $\begin{array}{c}8 \\
(13.33)\end{array}$ & $\begin{array}{c}12 \\
(20)\end{array}$ & $\begin{array}{c}27 \\
(45)\end{array}$ & $\begin{array}{c}13 \\
(21.67)\end{array}$ \\
\hline iii. & $\begin{array}{l}\text { Lack of Capital and Financial } \\
\text { sources and no saving culture. }\end{array}$ & - & - & $\begin{array}{c}6 \\
(10)\end{array}$ & $\begin{array}{c}42 \\
(70)\end{array}$ & $\begin{array}{c}12 \\
(20)\end{array}$ \\
\hline iv. & $\begin{array}{l}\text { Poor technical and technology } \\
\text { support (including power facility) }\end{array}$ & - & $\begin{array}{c}11 \\
(18.33)\end{array}$ & $\begin{array}{c}13 \\
(21.67)\end{array}$ & $\begin{array}{c}26 \\
(43.33)\end{array}$ & $\begin{array}{c}10 \\
(16.67)\end{array}$ \\
\hline v. & $\begin{array}{l}\text { Poor productivity and less quality } \\
\text { product }\end{array}$ & $\begin{array}{c}4 \\
(6.67)\end{array}$ & $\begin{array}{c}10 \\
(16.67)\end{array}$ & $\begin{array}{c}10 \\
(16.67)\end{array}$ & $\begin{array}{c}28 \\
(46.67)\end{array}$ & $\begin{array}{c}8 \\
(13.33)\end{array}$ \\
\hline vi. & Lack of market information $\&$ access & - & $\begin{array}{c}14 \\
(23.33)\end{array}$ & $\begin{array}{c}14 \\
(23.33)\end{array}$ & $\begin{array}{c}22 \\
(36.67)\end{array}$ & $\begin{array}{c}10 \\
(16.67)\end{array}$ \\
\hline vii. & $\begin{array}{l}\text { Lack of transportation and timely } \\
\text { import or export of goods }\end{array}$ & - & $\begin{array}{c}18 \\
(30)\end{array}$ & $\begin{array}{c}12 \\
(20)\end{array}$ & $\begin{array}{c}20 \\
(33.33)\end{array}$ & $\begin{array}{c}10 \\
(16.67)\end{array}$ \\
\hline viii. & $\begin{array}{l}\text { Wrong place of business or Miss } \\
\text { usage of work premises }\end{array}$ & $\begin{array}{c}8 \\
(13.33)\end{array}$ & $\begin{array}{c}7 \\
(11.67)\end{array}$ & $\begin{array}{c}7 \\
(11.67)\end{array}$ & $\begin{array}{c}30 \\
(50)\end{array}$ & $\begin{array}{c}8 \\
(13.33)\end{array}$ \\
\hline ix. & Highly competitive environment & - & - & $\begin{array}{c}12 \\
(20) \\
\end{array}$ & $\begin{array}{c}35 \\
(58.33) \\
\end{array}$ & $\begin{array}{c}13 \\
(21.67)\end{array}$ \\
\hline X. & Government and tax regulations & - & - & $\begin{array}{c}20 \\
(33.33)\end{array}$ & $\begin{array}{c}23 \\
(38.33)\end{array}$ & $\begin{array}{c}17 \\
(28.33)\end{array}$ \\
\hline
\end{tabular}

Table 5 provides the information about challenges facing by Growth oriented enterprises. Here also same challenges we have considered which we discussed in the previous. Bet here respondents shared different experiences with same type of challenge some time completely differ with livelihood enterprises.

In the growth oriented enterprises, only $36.67 \%$ respondents accepted the first challenge. Most of the respondents expressed without education running the enterprise is very difficult but especially in growth oriented enterprises no one enter without educational knowledge. Lack of education is not a major challenge because most of the 
respondents were completed their school level. This is quite opposite response compare with livelihood. Their most of the respondents accepted lack of education is major challenge but here respondents disagreed with their opinion. Here respondents have some special business skills, marketing skills, more over they have good awareness on their business. Some respondents mentioned lack of family support also one of the challenge. When they are going for out sourcing of employee services, most of the times failing to get proper commitment in the work. If family members are takes the responsibility of enterprises there is a scope to earn more.

When we come to the lack of financial support, $90 \%[70+20]$ of respondents agreed that this is a major challenge. High collateral guarantee and high bank interest rates are showing major cause. Frequently financial institutions are not providing proper loans to them for Purchasing equipments, machinery and raw material. Business size and individual properties are not that much sufficient to get proper loans from financial institutions. Any long time scarcity appeared in demand and supply, they cannot survive from the financial hurdles. Another challenge is technical and power problem facing by growth oriented enterprises. Especially for timber \& furniture, metal engineers are suffering with lack of technical equipments. Quality machines and new technology is not available in their work. Still they are depending on manual skills. Power problems also interrupting them but few only mentioned that.

Poor productivity and technical problems are interlinked challenges in growth oriented enterprises. $60 \%$ $[46.67+33.33]$ of respondents agreed poor productivity is also one of the biggest problems to the enterprises. Because of raw material scarcity, unskilled labour, limited technology, some productive oriented enterprises like bread making factories, furniture manufactures, and metal workers are producing less quality product. Especially in furniture and metal works they are not getting effective finishing like machine made. More bargaining nature of the customers, high competitions is pressuring them to reduce the selling price. Finally, they are making less quality items.

$53.33 \%$ respondents for lack of Market information, 50\% for lack of transportation and $63 \%$ for wrong place selection \& misuse of premises agreed. In present days, mobile internet, television and radio services are available all over the world. In case of Aksum town, some owners are not using internet services and not watching Televisions as regular habit. Based on that, enterprises are not getting updated information about market rates and other information of the products. Most of the enterprises are not in right place. They invested huge amount for failed to attract the customers. Super markets, restaurants are facing these types of challenges. Another challenge is high competition environment. General stores, restaurants, furniture, metal businesses and beauty salons are facing this problem. Almost $80 \%$ of enterprisers agreed this. Finally, government and tax problems agreed by $2 / 3$ respondents. Most of the respondents are not comfort with high rate of taxes, Government rules, and controlling, inspection also very high.

Table 6:- A table for Ranks allotted based on all agreed \%

\begin{tabular}{|l|c|c|c|c|c|c|c|c|c|c|}
\hline No.of Challenges > & i. & ii. & iii. & iv. & v. & vi. & vii. & viii. & ix. & x. \\
\hline Livelihood enterprises > & 3.5 & 2 & 1 & 9 & 6.5 & 6.5 & 8 & 5 & 3.5 & 10 \\
\hline Growth enter prises > & 10 & 3.5 & 1 & 6.5 & 6.5 & 8 & 9 & 5 & 2 & 3.5 \\
\hline Rank difference > & $(6.5)$ & $(1.5)$ & -- & 2.5 & -- & $(1.5)$ & $(1)$ & -- & 1.5 & 6.5 \\
\hline
\end{tabular}

$r_{\mathrm{s} 12}=+0.605$

Under table-6, researcher compared both enterprise challenges based on spearman's rank correlation. This study contains almost ten common challenges in livelihood as well as growth oriented enterprises. Researcher gave serial numbers like i, ii, iii, .... and compared every challenge in both enterprises and also compared rank deviations.

This comparison strongly shows the equality in challenge iii named as "lack of capital, financial sources and saving culture". In both enterprises, this challenge stood on 1st place. Either big or small, enterprises are struggling more for financial sources. As our early discussion, livelihood enterprises mostly depending on unstructured markets for collecting the amount with high interest rates and growth oriented enterprises are also struggling with collateral arrangements. Respondents, expressed same opinion on $\mathrm{V}^{\text {th }}$ and $\mathrm{Viii}{ }^{\text {th }}$ challenges named as poor productivity and wrong place of selection. In the ranking table, both places came $5^{\text {th }}$ and 6.5 places. These ranks are not occupied from 1 to $4^{\text {th }}$ ranks. Even though, this study must give priority to challenges as per their ranks.

Respondents expressed quite opposite opinion on challenge (i) and (x). Most of the livelihood enterprises were agreed that lack of education and business entrepreneur skills are major challenge to distress the entrepreneurs. 
Remaining enterprises are completely ditching the livelihood entrepreneurs with new business strategies. Based on this $1^{\text {st }}$ challenge occupied 3.5 rank in livelihood entrepreneurs. Another end, growth oriented entrepreneurs gave $10^{\text {th }}$ rank to the same challenge. These respondents completely differed with livelihood enterprises. As per their opinion, most of the entrepreneurs have minimum educational background and minimum business skills. Growth oriented enterprises are facing financial, technical and other challenges but not educational backgrounds. In case of (xth) challenge [Government and tax challenges], livelihood entrepreneurs gave $10^{\text {th }}$ rank and growth oriented enterprises gave $3.5^{\text {th }}$ rank. Government rules and regulations are not showing any impact on livelihood enterprises but growth oriented enterprises are struggling with government rules, licence system and tax barricades. Remaining ranks are little bit similar in both enterprises. Finally, the Co-relation shows 0.605 between two enterprises. This result shows that, high positive relations in both enterprise challenges.

\section{Conclusion:-}

An assessment of challenges faced by livelihood \& growth oriented enterprises is a most impertinent research to identify the practicality and real situation in Aksum town. Under the Ethiopian circumstances millions of entrepreneurs surviving by livelihood businesses. New industrial policies in Ethiopia attracting the new investors and day by day thousands of growth oriented entrepreneurs are coming. Most of the researchers found different challenges but identification of challenges not only sufficient, Finding the impact and range of challenges are also plays an important role. Researcher have been discussed various challenges in livelihood and growth oriented enterprises and found the possible reasons. Aksum town is a small town and huge investment high productivity enterprises are not available even though respondents expressed their views as similar to SMSE's. This study succeeded to provide ranks to different types of challenges which are facing by enterprises and also study useful to estimate the severity of challenges. Based on this study, iii, ii, vii, viii, ix ${ }^{\text {th }}$ challenges are disclosing the high impact of challenges. Government, Investors and entrepreneurs can easily estimate their strategies about the enterprises. Ranks and rank deviations were clearly explained the difference between livelihood and growth oriented enterprises surviving struggles.

\section{References:-}

1. Charles Harvie, 2004, ISBN 1840648082 sustaining growth and performance in east asia.

2. Caroline Reeg-Discussion Paper / Deutsches Institut für Entwicklungspolitik ISSN 1860-0441 (adapted from Rogerson 1996; Berner / Gomez / Knorringa 2008; Reynolds et al. 2005; Altenburg / Meyer-Stamer 1999)

3. Source: Federal Micro and Small Enterprise development agency, Addiss abab Ethiopia. Implementation, success and challenges of Micro and Small Enterprises (MSEs) development in Ethiopia

4. Samuel Muriithi, European Journal of Research and Reflection in Management Sciences, Vol. 5 No. 1,2017 ISSN 2056-5992

5. International Journal of Science and Research (IJSR) ISSN (Online): 2319-7064 Volume 5 Issue 10, October 2016 www.ijsr.net Critical Success Factors of Micro \& Small Enterprises in Ethiopia: A Review Vijay Joshi (PhD)1, Gebreselassie Mihreteab2

6. Desalegn Berhane Asgedom International Journal of Science and Research (IJSR) ISSN (Online): 2319-7064, Challenges and Opportunities of Micro and Small Munifacturing Enterprises the Case of Easter Zone of Tigray

7. National Credit Regulator-2012, literature review on small and medium enterprises' access to credit and support in south Africa.

8. Butale H.S. (2001). Urban Informal Sector Profile, Linkages and Constraints: A case of Francistown, Botswana. MSC Dissertation, University of Botswana

9. Bharan N. (2004). Employment and poverty alleviation. Ministry of Urban, Government of India

10. Nakisani Carol, Chicho-Matenge, International Journal of Learning \& Development ISSN 2164-4063 2013, Vol. 3, No. 5, An Assessment of Challenges faced by Microenterprises in Botswana: A case of Street Food Vendors in Gaborone

11. Asiedu, E, James AF and Nti-Addae, A (2012) Access to Credit by Small Businesses: How Relevant Are Race, Ethnicity, and Gender? American Economic Review, 102(3): 532-37.

12. Hyder, S. and Lussier, R. N. (2016): Why businesses succeed or fail: a study on small businesses in Pakistan, Journal of Entrepreneurship in Emerging Economies, 8 (1), 82-100.

13. Yang, J. (2011): Business environment perceptions in Afghanistan and Pakistan, Enterprise Surveys, World Bank Enterprise Note No. 27.

14. Cant, M (2012) Challenges faced by SME's in South Africa: are marketing skills needed? International Business \& Economics Research Journal 11(10): 1107-1116. 
15. Lee D, Lee SM, Olson DL and Chung SH (2010) The effect of organizational support on ERP implementation. Industrial Management \& Data Systems 110(2): 269-283.

16. Management, Vol. 21, 2016, 2, pp. 45-76 S. Petković, C. Jäger, B. Sašić: Challenges of small and medium sized companies at early ... 46

17. Fjose, S., Grunfeld, L. A. \& Green, C. (2010). SMEs and growth in Sub-Sahara Africa: Identifying SME Role and obstacles to SME growth. MENON-Publication, 14, 1-28.

18. Ericson R, Pakes R. Markov perfect industry dynamics: A framework for empirical work, review of economic studies. 1995;62(1):53-82.

19. Fatai, A. (2011). "Small and Medium Scale Enterprises in Nigeria: The Problems and Prospects".RetrievedJanuary15fromwww.thecje.com/journal/index.php/economicsjour nal/article/.../8.

20. Francis Kwesi Bondinuba, Civil and Environmental Research, ISSN 2222-1719 (Paper) ISSN 2222-2863 (Online), Vol 2, No.6, 2012 "Exploring the Challenges and Barriers in Accessing Financial Facilities by Small and Medium Construction Firms in Ghana". 